\title{
BIO-BRICK - DEVELOPMENT OF SUSTAINABLE AND COST EFFECTIVE BUILDING MATERIAL
}

\author{
Rautray, Priyabrata (1); Roy, Avik (2); Mathew, Deepak John (1); Eisenbart, Boris (3) \\ 1: IIT Hyderabad; 2: KIIT Bhubaneswar; 3: Swinburne University of Technology
}

\begin{abstract}
Building construction is one of the fastest growing industries in India and it puts a huge burden on its limited natural resources. Fired clay bricks are one of the major constituent materials for the construction industry and it produces a huge amount of greenhouse gases. This research tries to highlight the use of alternative materials and how they can be modulated to suit the Indian construction industry. Bio-brick or agro-waste based brick is one such material that has the potential to be a sustainable and cost-effective solution. It acts as good heat and sound insulator and at the same time has overall negative carbon footprint. Additionally, it also acts as a deterrent to stubble burning, prevalent in northern India which causes severe air pollution. Due to its low density, it reduces dead load in high rise structures, thereby making RCC construction more economical. The study also highlights the use of Bio-brick in various areas of a structure. Another important objective of this research is to inspire and motivate architects, designers, researchers and builders to encourage and support the development of such sustainable and eco-sensitive material in construction industry.
\end{abstract}

Keywords: Sustainability, Ecodesign, New product development

\section{Contact:}

Rautray, Priyabrata

IIT Hyderabad

Design

India

md17resch11001@iith.ac.in 


\section{INTRODUCTION}

Construction is the second largest industry in India, only second to agriculture. With rapid urbanization and exponential growth of population, there is a huge demand for housing and other ancillary related to housing creating a shortage of conventional building materials. The production of conventional building materials consumes a lot of energy and pollutes air, water and land. Thus, to meet the ever-increasing demand of building materials, new sustainable materials are needed (Madurwar et al., 2013). At the same time, there is a growing issue of solid wastes from agriculture, which have become a major source of air pollution not only in India, but in almost all developing countries (Awasthi et al., 2010).

The main aim of the research presented in this paper is to find a constructive method to turn solid, agricultural wastes into viable building materials, thereby addressing both pressing issues at the same time. The present paper explores the potential application of 'agro-waste', like hey or straw stubbles, leftover wood, et cetera, as the ingredient for alternative sustainable construction materials in the form of bricks. Based on the availability of agro-waste materials, these bio-bricks can be modified to suit the local market and building construction styles. The application of agro-waste as a construction material can result in the reduction of the usage of natural resources as well as of energy consumption. At the same time, it can add to the farmer's income, who can sell the leftover stubbles instead of burning them, thereby reducing air pollution. To achieve this goal, the process of up-cycling (the process of converting waste materials into new products of better environmental value than in their previous use) (Oyenuga et al., 2017) can be used to convert the agro-waste into usable bricks by combining it with lime, stone dust and water.

The paper is divided into two parts, the first part highlights the growth of construction and agriculture sectors in developing countries like India and its adverse impact on environment. The second part of paper elaborates the process of making the bio-brick, its advantages, it's probable uses in construction industries and direct benefits to the environment. Thus, through our research paper we want to explore the potential use and possibilities of bio bricks in construction industries.

\section{GROWTH OF CONSTRUCTION INDUSTRY: INDIAN STORY}

\subsection{Construction industry}

India along with China are the two fastest growing economies on the globe with huge investments in the field of construction. In the year 2015 alone, the construction industry in India grew by around 20$30 \%$. The Indian government's 'Smart City' initiative is expected to attract an investment of more than 2 trillion rupees. Other Government initiatives like 'Housing for All by 2022' will be a further boost to the construction industries (Pandit, 2017). Through these initiatives, by 2018, the growth in the construction industry is expected to double as compared to the year 2015. Looking into the future, the industry is expected to receive around $\$ 650$ billion dollars of investment in next 20 years (Morris, Anindo Sarkar, Udayan Dhavalikar, 2016). Such a massive growth of the construction industry will demand huge amounts of raw materials to fuel new buildings being put up, thus exacerbating the mentioned problems in terms of material demand and pollution. The use of common building materials like sand, clay bricks, cement or steel is growing at an alarming rate thereby making these materials expensive and scarce. As a result, there is an increase of illegal mining leading to substantial, uncontrolled degradation of the natural environment. What these numbers highlight is how imperative it is to find more sustainable and environmental friendly solutions.

\subsection{Demand of raw material}

By the year 2030, about 590 million people in India are expected to live in cities. Such a level of urbanisation will need large investments in the field of housing (Loganathan et al., 2017). India's raw material requirements are expected to be around 15 billion tonnes by 2030 and around 25 billion tonnes by 2050 (Satpathy et al., 2016). Many resources are located in ecologically sensitive zones such as river basins including those of the Palar and its tributaries Cheyyar (Tamil Nadu) (Saviour, 2012) and extracting materials is going to affect them adversely. River sand, for instance is the most preferred choice in the construction sector due to the presence of silica, which is inert, hard and durable. This fuels rampant extraction of river sand which leads to the destruction of river systems. This often involves unorganised groups which makes it difficult for the state to regulate the activities of the sand mining industry and it 
proliferates owing to low investments and high returns. Some reports have indicated an amount of INR 10 billion (USD 150 million) being generated from illegal extraction of sand in India in 2011. Extraction per area in India is the highest in the world i.e. around 1579 tonnes/ sq.km compared to 454 tonnes/ sq.km worldwide (Satpathy et al., 2016). Since material costs for the majority of the expenditure in a building, current situation demands efficient material usage and options of alternate building solutions.

\subsection{Pollution and destruction of nature}

The Central Pollution Control Board (CPCB) has estimated that India has around 140,000 brick kilns producing 66 million tonnes of emissions of $\mathrm{CO} 2$. It also produces harmful pollutants such as Carbon monoxide (CO), Sulphur Dioxide (SO2), Nitrous Oxides (NOx), particulate matters, etc. These kilns cause approximately $9 \%$ of the total green-house emissions in India (Aswale, 2015). Besides emissions, the bricks use around 350 million tons of top soil and clay which leads to soil erosion, potentially leading to a huge environmental disaster (Banerjee, 2015). With increased mining ecological degradation is becoming rampant along with increased conflicts. Large scale extraction will further increase carbon emissions making it difficult for India to meet the International Climate change commitments.

\section{AGRICULTURE INDUSTRY IN INDIA}

\subsection{Agricultural waste}

After China, India is the second largest producer of agricultural waste. It produces more than 130 million-tons of Paddy straw out of which only half is used as fodder and the other half goes to waste, either in landfills or is simply dumped somewhere (Baig, 2010; Singh and Sidhu, 2014). It also produces more than 50 million-tons of cane bagasse. Table 1 (Jain et al., 2014) indicates the state wise generation of agricultural waste across India. As can be seen, India has diverse agricultural practices, which produces more than 500 million-tons of agricultural waste every year. The surplus waste (84 141 million-tons) is usually burnt by the farmers which results in massive air pollution causing major health hazards. A study based on Punjab alone showed that stubble produced per acre of paddy and wheat is around 23 and 19 quintals respectively. Around $85 \%$ of the paddy stubble is burnt in the open fields. In the case of wheat stubble around $11 \%$ was burnt. Considering the amount of stubble being produced, even burning a smaller percentage of it can cause considerable damage to the environment around it (Singh, 2017).

Table 1. Crop wise residue generated [Mt/year] in various states of India

\begin{tabular}{|l|l|l|l|l|}
\hline States & Cereal crops & Fibre crops & Oilseed crops & Sugarcane \\
\hline Andhra Pradesh & 33.07 & 16.07 & 2.50 & 5.80 \\
\hline Arunanchal Pradesh & 0.56 & 0.00 & 0.06 & 0.01 \\
\hline Assam & 8.15 & 2.01 & 0.29 & 0.41 \\
\hline Bihar & 19.87 & 3.27 & 0.20 & 1.87 \\
\hline Chhattisgarh & 8.87 & 0.01 & 0.11 & 0.01 \\
\hline Goa & 0.24 & 0.00 & 0.01 & 0.02 \\
\hline Gujarat & 8.18 & 28.62 & 5.06 & 5.85 \\
\hline Haryana & 24.73 & 7.58 & 2.15 & 1.93 \\
\hline Himachal Pradesh & 1.95 & 0.00 & 0.01 & 0.02 \\
\hline Jharkhand & 7.34 & 0.00 & 0.09 & 0.13 \\
\hline Karnataka & 11.73 & 3.55 & 0.81 & 8.80 \\
\hline Kerala & 1.14 & 0.01 & 0.00 & 0.10 \\
\hline Madhya Pradesh & 16.05 & 3.51 & 2.13 & 1.12 \\
\hline Maharashtra & 8.75 & 19.51 & 0.57 & 22.87 \\
\hline Manipur & 0.78 & 0.00 & 0.00 & 0.01 \\
\hline Meghalaya & 0.44 & 0.13 & 0.01 & 0.00 \\
\hline Mizoram & 0.10 & 0.00 & 0.00 & 0.01 \\
\hline Nagaland & 0.89 & 0.01 & 0.06 & 0.07 \\
\hline Orissa & 13.38 & 0.56 & 0.16 & 0.24 \\
\hline Punjab & 45.58 & 9.32 & 0.08 & 1.76 \\
\hline
\end{tabular}




\begin{tabular}{|l|l|l|l|l|}
\hline Rajasthan & 22.19 & 2.96 & 9.26 & 0.15 \\
\hline Sikkim & 0.14 & 0.00 & 0.01 & 0.00 \\
\hline Tamil Nadu & 11.69 & 0.78 & 1.56 & 12.37 \\
\hline Tripura & 1.22 & 0.02 & 0.00 & 0.02 \\
\hline Uttar Pradesh & 72.02 & 0.04 & 2.49 & 41.13 \\
\hline Uttarakhand & 2.40 & 0.00 & 0.03 & 2.11 \\
\hline A \& N Islands & 0.04 & 0.00 & 0.00 & 0.00 \\
\hline D \& N Haveli & 0.05 & 0.00 & 0.00 & 0.00 \\
\hline Delhi & 0.17 & 0.00 & 0.00 & 0.00 \\
\hline Daman \& Diu & 0.01 & 0.00 & 0.00 & 0.00 \\
\hline Pondicherry & 0.10 & 0.00 & 0.00 & 0.06 \\
\hline All India & 361.85 & 122.37 & 28.72 & 107.50 \\
\hline
\end{tabular}

\subsection{Agricultural waste in india}

The Indo Gangetic plains is the highest affected region in terms of crop burning. Along with other causes of pollution, it creates a poisonous haze every year causing widespread respiratory hazards and even mortalities. The resulting smoke can cause multiple and lasting effects particularly on children's lung function compared to adults. It also causes permanent decrease in their pulmonary function which in due course can lead to lowering the respiring capacity of the adult and thus lead to major epidemiological hazards (Awasthi et al., 2010).

In Delhi, India's largest city, the pollution due to crop burning has doubled between the years 1995 to 2015. The pollution in Mumbai has increased by 1.5 times during the same period. There were approximately 80665 deaths that were directly or indirectly caused by air pollution in the year 2015 alone (PHFI and CEH, 2017). Though crop burning cannot be held solely responsible for the situation, it nonetheless is an important contributor to the crisis. Refer to Table 2 (Jain et al., 2014) for crop wise residue generation and fraction burnt in India. The table highlights the high annual production of crops like rice paddy and sugarcane, the higher amount of residue generation contrary to their low residue to crop ratio. Thereby, these crops by their sheer volumes become the major contributors to Agriculture Crop Residue Burning (ACRB). This also shows the enormous potential, if all of this waste could be used somehow as a sustainable and economically profitable material, which will be beneficial not only for India but also for the world.

Table 2. Crop wise waste generated and fraction burnt

\begin{tabular}{|l|l|l|l|l|l|}
\hline Crop & $\begin{array}{l}\text { Annual } \\
\text { production } \\
(\mathrm{Mt} / \mathrm{yr})\end{array}$ & $\begin{array}{l}\text { Dry Residue } \\
\text { Generated } \\
(\mathrm{Mt} / \mathrm{yr})\end{array}$ & $\begin{array}{l}\text { Residue to } \\
\text { crop ratio }\end{array}$ & $\begin{array}{l}\text { Dry matter } \\
\text { fraction }\end{array}$ & $\begin{array}{l}\text { Fraction } \\
\text { burnt }\end{array}$ \\
\hline Rice paddy & 153.35 & 192.82 & 1.50 & 0.86 & $0.08-0.8 \#$ \\
\hline Wheat & 80.68 & 120.70 & 1.70 & 0.88 & $0.1-0.23^{*}$ \\
\hline Maize & 19.73 & 26.75 & 1.50 & 0.88 & 0.10 \\
\hline Jute & 18.32 & 31.51 & 2.15 & 0.80 & 0.10 \\
\hline Cotton & 37.86 & 90.86 & 3.00 & 0.80 & 0.10 \\
\hline Groundnut & 7.17 & 11.44 & 2.00 & 0.80 & 0.10 \\
\hline Sugarcane & 285.03 & 107.50 & 0.40 & 0.88 & 0.25 \\
\hline Rapeseed \&Mustard & 7.20 & 17.28 & 3.00 & 0.80 & 0.10 \\
\hline Millets & 18.62 & 21.57 & 1.50 & 0.88 & 0.10 \\
\hline Total & 627.96 & 620.43 & & & \\
\hline
\end{tabular}

\# Gadde et al. (2009). * 0.23 is for Haryana, Punjab, H.P., U.P.

\section{SUSTAINABLE DEVELOPMENT}

Sustainability is defined as a development that satisfies the needs of the present without compromising the capacity of future generations, guaranteeing the balance between economic growth, care for the environment and social well-being (UN, 1987). It highlights the negative environmental consequences of economic growth and globalization, and through sustainable development it tries to find possible solutions to the problems caused by industrialization and population growth. 
The United Nation Environment Program estimates that buildings consume about $40 \%$ of the world's energy, $25 \%$ of the water, and also about $40 \%$ of the material resources in construction. Buildings are also responsible of about $1 / 3$ of greenhouse gas emissions of the whole planet (Asdrubali et al., 2015) making construction industries as one of the largest polluters and exploiters of natural resources. Thus pursuing new sustainable materials and construction technologies can greatly reduce the stress on the environment both directly and indirectly.

As shown in Figure 1 (Hammond and Jones, 2008), brick and concrete are the major contributors to carbon footprint as compared to other building materials. The average carbon footprint of the bricks manufactured is estimated as $195 \mathrm{~g} \mathrm{CO} 2 / \mathrm{kg}$ including the fuel and transportation (Kulkarni and Rao, 2016).

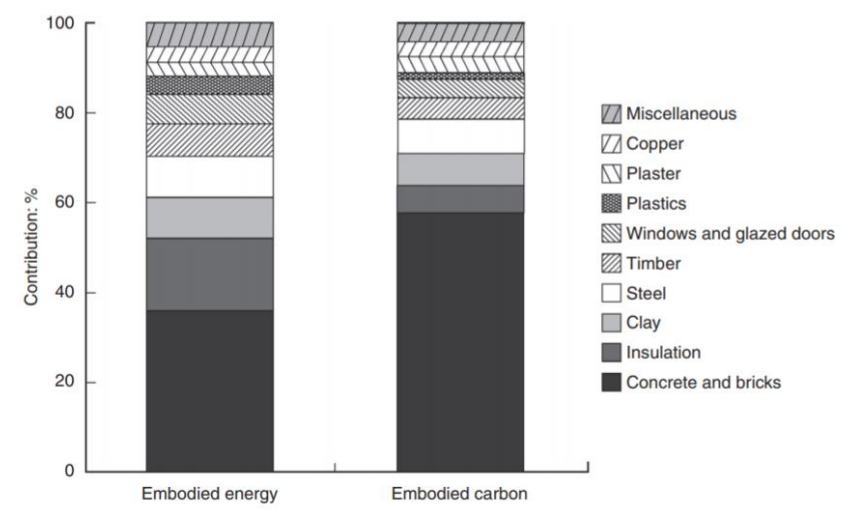

Figure 1. Constituent raw materials for building

There are several sustainable alternatives that are being currently used in construction industries. Some of the most prevalent ones are fly ash, recycled concrete, foam concrete, agro-based panel boards, recycled materials boards, silica fumes, recycled tires, et cetera (Meyer, 2009). A precursory study clearly suggested that the manufacturing technology of so-called 'hempcrete' can be modified best to suit the agro-waste generated in India. Hempcrete which is manufactured primarily from the residue of Hemp plant. Hempcrete is one of the most explored Bio-Crete which is a composed by mixing lime binder, water and the non-fibrous part of hemp, called 'shiv'. With passage of time the composition hardens and can be used as bricks. Figure 2 (Magwood, 2017) shows the constituent materials of hempcrete and Figure 3 (Armstrong, 2015) highlights the advantages of hempcrete as a building material.

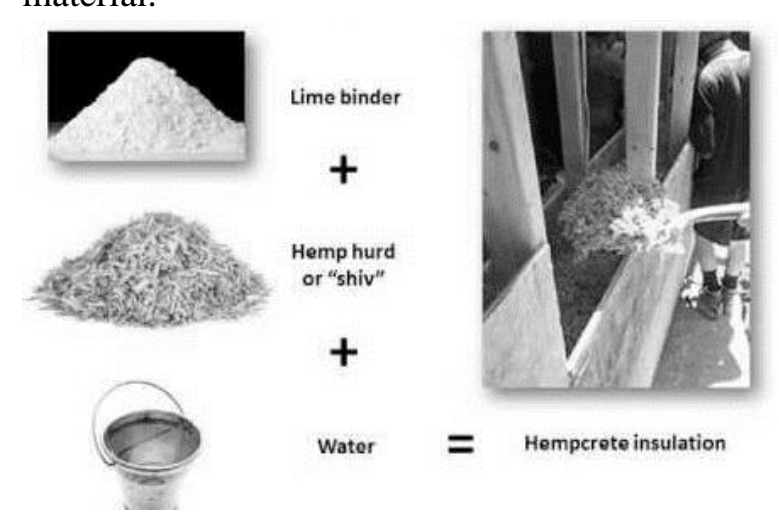

Figure 2. Constituent raw materials

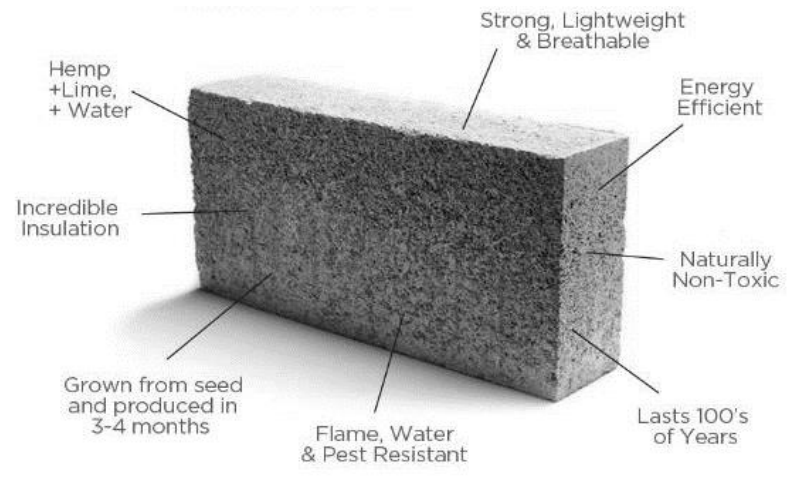

Figure 3. Benefits of hempcrete

Bio-bricks being a new material, not much of research is done to evaluate its end-of-life usages and disposal. As there is no decomposition of the material, the absorbed carbon dioxide stays locked in it (Prétot et al., 2014). We propose that, at the end-of-life, these bio-bricks could be pulverised and mixed with new bio-mass to make new bio-bricks rather than ending as landfills. 
The overall emission balance is very favourable, due to the result of biogenic $\mathrm{CO} 2$ uptake during hemp growth and $\mathrm{CO} 2$ uptake by carbonation, hempcrete blocks have a negative carbon footprint and therefore act as effective carbon sink. This is the dual benefit of such innovative building material where along with its excellent heat insulation and sound absorption qualities, it acts as a good sustainable building material (Arrigoni et al., 2017). Figure 4 (Arrigoni et al., 2017) showcase how hempcrete block acts as a carbon sink or carbon negative building material. Firstly, atmospheric carbon dioxide is taken by the plant during their growth and is locked in the plant cellulose. Secondly, by the process of carbonation, the calcium hydroxide absorbs carbon dioxide to form more stable calcium bicarbonate or calcium carbonate. Thus, the amount of carbon dioxide produced in making hempcrete block is less as compared to carbon dioxide retained in the hempcrete block, making it a very sustainable building material. It can be an effective solution for pollution caused by burning agro-wastes and satisfy the growing need for construction materials.

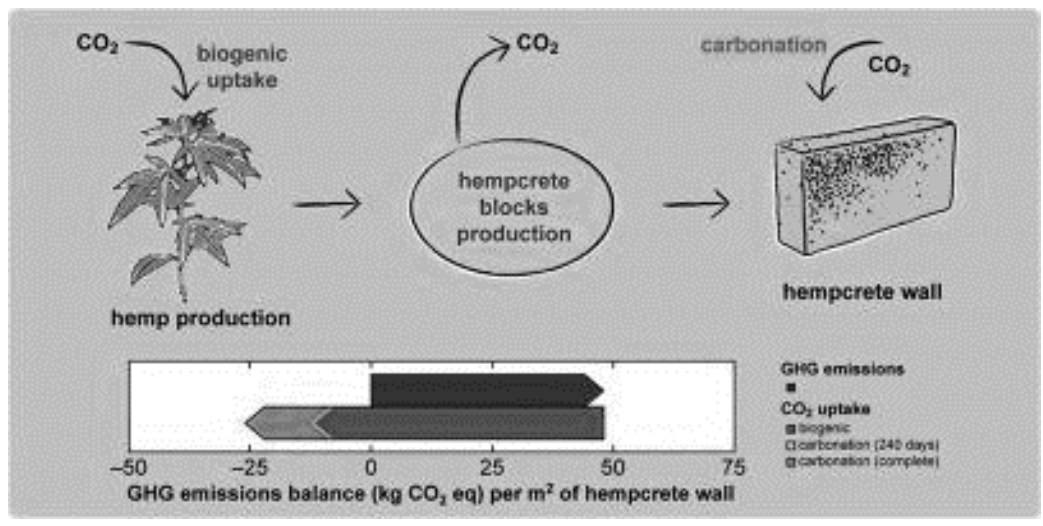

Figure 4. Negative carbon foot print of hempcrete

\section{DESIGN AND DEVELOPMENT}

During our initial research (Jain et al., 2014) it was evident that huge quantities of residual agro-waste (refer Table 1) is generated in India, which are generally disposed of by burning due to its negligible economic value. This leads to severe air pollution and health hazard. At the same time India has large construction industry and the demand for raw material is growing exponentially. Consumption of bricks is higher as compared to all other building materials, leading to loss of fertile top soil and pollution caused by kiln firing (Gadling and Varma, 2016). This research paper attempts to resolve both these issues by developing a building material that would convert the agro-waste into a valuable and sustainable resource for the construction industries, resulting into a symbiotic economic model. A modified method similar to the manufacturing of hempcrete can be used to create these agro-based biobricks.

The process of making bio-brick starts with careful selection of the dry agro-waste, which is then chopped to the desired size. A lime based slurry is prepared by adding slake lime, binder, stone dust and water. The chopped agro-waste is added to the slurry and mixed thoroughly by hand or mechanical mixer, to create a homogenous mixture. This mixture is poured into moulds $(150 \mathrm{~mm} \mathrm{x} 150 \mathrm{~mm} \mathrm{x}$ $150 \mathrm{~mm}$ ) and rammed with wooden block to make a compact brick by removing extra water or voids. These moulds are left to dry for a day or two, after which the sides of the moulds are removed and the brick is allowed to dry for fifteen to twenty days. It takes approximately a month's time for these biobricks to attain its working strength by air drying.

In this process no controlled or machine drying is used to make the whole process sustainable and reduce the carbon footprint. The time taken to manufacture bio-bricks is comparable to air dried (naturally dried) fired clay bricks. After a month of drying, bio-bricks are covered by a rigid skin, mostly made up of carbonate lime (calcination) thereby increasing its overall strength. Even though these bio-bricks have less compressive strength as compared to fired clay bricks or concrete blocks, they are quite light in weight (1.43 kg per block) i.e. almost 1/8 of fired clay bricks and 1/10 of concrete blocks of similar volume. Hence, they can be effectively used in framed structure as non-load bearing walls with excellent heat and sound insulation with minimal dead load on the structure. 


\subsection{Prototyping - with sugar cane bagasse and wheat husk}

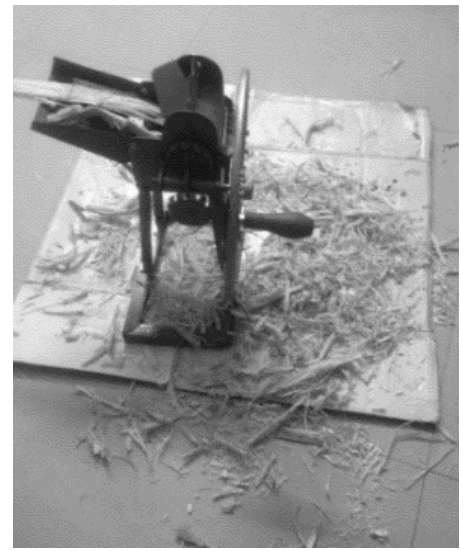

Figure 5. Dry sugarcane bagasse was chopped into fine

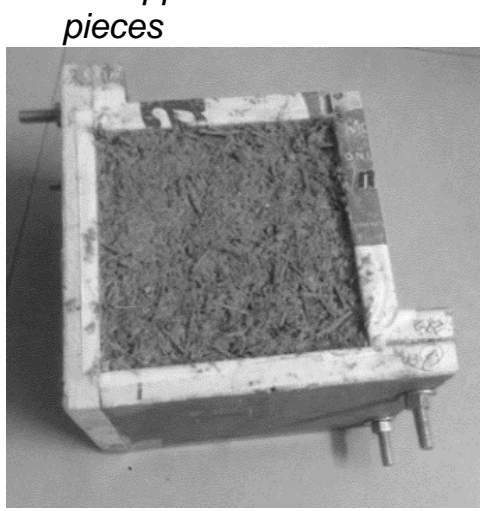

Figure 8. The mixture is properly compacted into the mould

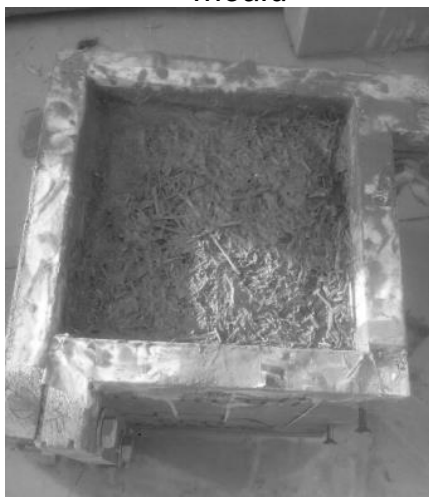

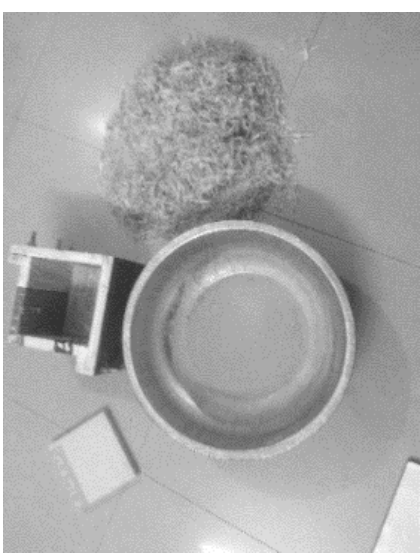

Figure 6. Basic tools used along with lime, stone dust and water

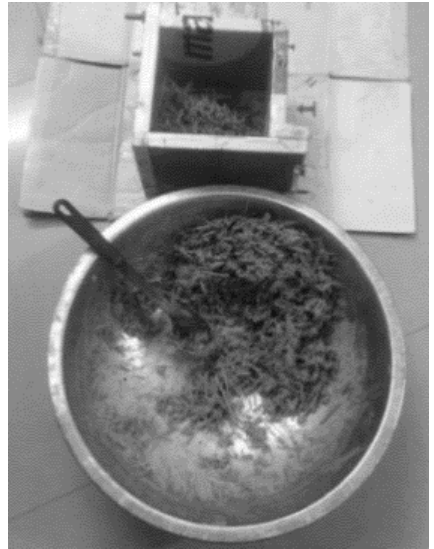

Figure 7. Chopped bagasse, lime, water and stone dust were mixed properly

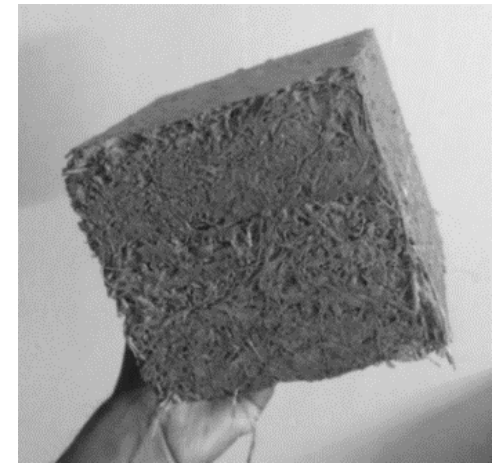

Figure 9. The bio-brick was allowed to dry in air for a month

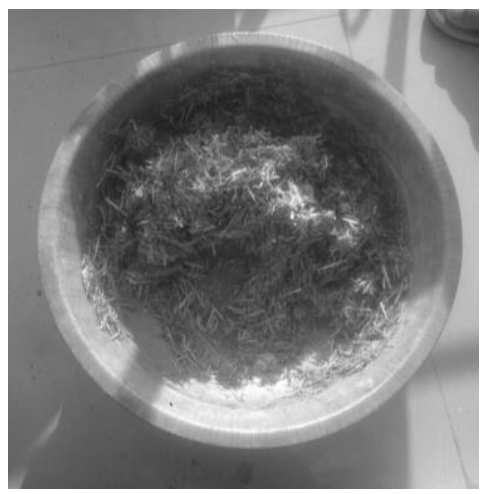

Figure 10. The same experiment was repeated with wheat husk

Figure 5 to Figure 9 highlights the lab experiments and the process of making bio-bricks. Figure 10 shows the bio-brick made out of wheat husk. For this, the ratio of the lime slurry needs to be calibrated to achieve right composition for the bio-bricks to suit the diverse agricultural wastes generated in India.

\subsection{Discussion of application, benefits and limitations of bio-bricks}

Bio-bricks as compared to burnt clay bricks is not only sustainable but also acts as a carbon sink as it fixes more carbon dioxide than it is produced during its lifecycle. For instance, in the prototype, the bio-brick made out of sugarcane bagasse, $900 \mathrm{gm}$ of sugarcane bagasse was used to make the block. Whereas, burning $1 \mathrm{~kg}$ of sugar cane bagasse produces around $710 \mathrm{gm}$ of carbon dioxide (Kulkarni and Rao, 2016). Thus, a single block of bio-brick made out of sugarcane bagasse can store around 639 $\mathrm{gm}$ of carbon dioxide. Furthermore, owing to the process of carbonation, atmospheric carbon dioxide is fixed as shown in the Equation 1 (El-Turki et al., 2007), fixes around $28.55 \mathrm{~kg}$ of carbon dioxide per 


$$
\mathrm{Ca}(\mathrm{OH})_{2(\mathrm{~s})}+\mathrm{CO}_{2(\mathrm{~g})} \rightarrow \mathrm{CaCO}_{3(\mathrm{~s})}+\mathrm{H}_{2} \mathrm{O}_{(1)}
$$

functional unit $(1 \mathrm{~m} \times 1 \mathrm{~m} \times 0.3 \mathrm{~m})$ wall. Bio-brick developed during the research can sequester $322.2 \mathrm{gm}$ of carbon dioxide per block (Ip and Miller, 2012). Thus, the net greenhouse gas emission during the life cycle of one bio-brick block is around $-1.015 \mathrm{~kg}$ of carbon dioxide, the negative value indicates an overall positive impact on environment.

Even though these bio-bricks cannot be used directly to build load bearing structures, they can be used in low cost housing with combination of wooden or metal structural frame works as shown in Figure 11. With low thermal conductivity (approx. $0.27 \mathrm{~W} / \mathrm{mK}$ ) (Son et al., 2017) these bio-bricks can be effectively used in walls as they provide good insulation to heat and sound. Due its porosity and low density these bio-bricks helps in maintaining humidity of the buildings, making these houses suitable for hot-humid climate like India (Walker and Pavía, 2014).

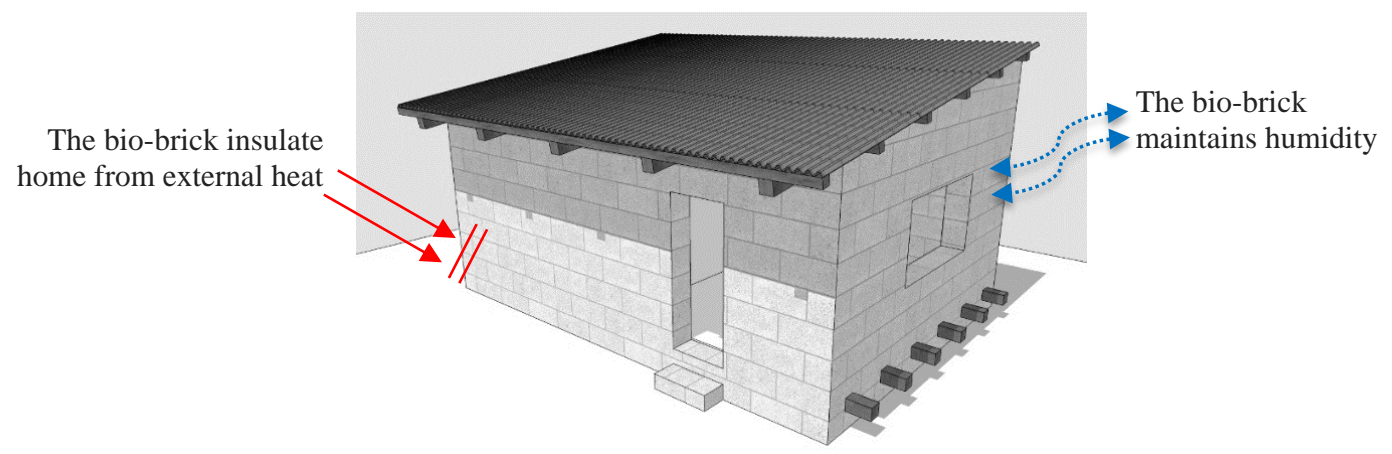

Figure 11. Low cost load bearing housing

Bio-brick with low average density of $423.7 \mathrm{~kg} / \mathrm{m} 3$ (as calculated from prototypes) is a suitable replacement of burnt clay brick and concrete block for partition walls in column beam structures. This is extremely beneficial for high rise structures as the overall load on the frame structure will be much lower compared to traditional walls as illustrated in Figure 12. Thus, this can result in designing lighter frame structure, thereby reducing the use of concrete, steel and lowering the construction cost.

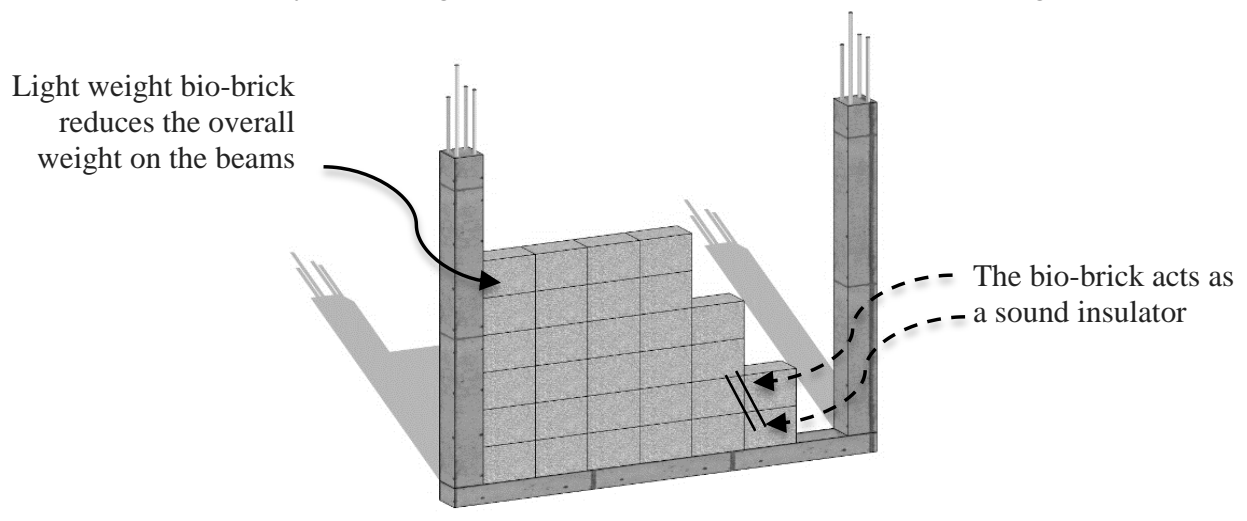

Figure 12. Filler wall material for column beam structure

Other than as bio-bricks, this material can be used as panel boards or insulation boards for creating comfortable living spaces as shown in Figure 13. In future as designers we could explore more uses for this sustainable material.

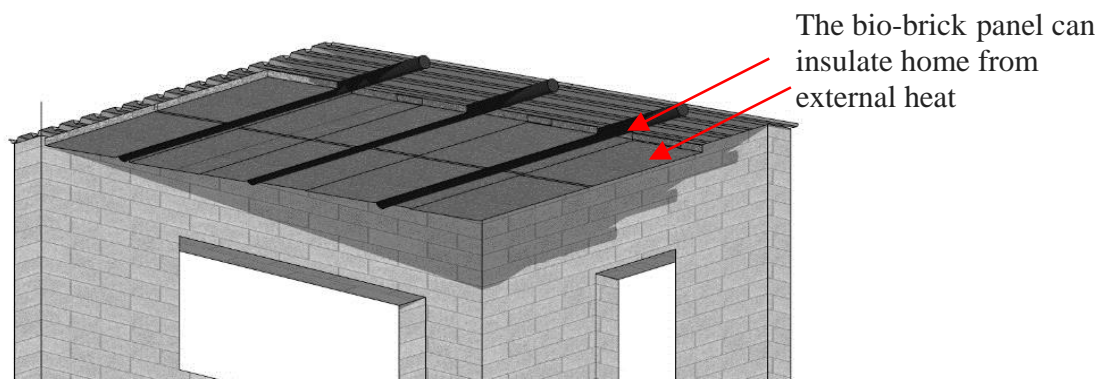

Figure 13. Used as an insulation material for corrugated sheet roofing 


\section{CONCLUSION}

India is home to a diverse range of agricultural crops and is among the top three producers of waste in the world. This generates a huge amount of agro-waste that needs to be disposed. At the same time, the demand for raw materials, especially bricks, is ever increasing for Indian construction industries. The bio bricks we generated from common agro-waste, have a tremendously better net carbon footprint than standard building materials and, at the same time, are very cheap and simple in production. Though they may not be suitable for larger loads, they have huge application potential in less-load bearing wall construction, sounds reduction and insulation, particularly in the low-cost sector, which, after all, is a substantial market in India. Thus, converting agro-waste into bio-bricks could help mitigating the pertinent issues of raw material required by construction industry and the agro-waste created in agricultural sector.

Given the identified limitations of the load-bearing capacities of bio-bricks, we expect government support and public awareness will be needed to make bio-bricks production turn into a self-sustaining industry. Following steps could help in proper development of this new material:

- Government initiative and incentives are required to promote and propagate the new material.

- Large scale awareness campaigns and training programs for grassroots' level masons and builders.

- Campaigns that are directed at informing target users (e.g. the farmers) by showcasing how the conversion of waste into bricks can benefit them.

- Showcasing how bio-bricks can become a major impact in improving the sustainable practice of Indian construction industry.

Further research and development is required to develop bio-bricks for pan-India application where local agricultural waste can be used as a building material. We will also need to explore options for how the load-bearing capacity of the bricks can be improved as well as how to optimise the manufacturing processes for the bio bricks to allow for industrial scale production at low cost.

\section{REFERENCES}

Armstrong, L. (2015), "Building a sustainable future: The hempcrete revolution", Www.Cannabusiness.Com, available at: http://www.cannabusiness.com/news/science-technology/building-a-sustainable-future-thehempcrete-revolution/ (accessed 4 August 2018).

Arrigoni, A., Pelosato, R., Melià, P., Ruggieri, G., Sabbadini, S. and Dotelli, G. (2017), "Life cycle assessment of natural building materials: the role of carbonation, mixture components and transport in the environmental impacts of hempcrete blocks", Journal of Cleaner Production, Elsevier Ltd, Vol. 149 No. October, pp. 1051-1061.

Asdrubali, F., D’Alessandro, F. and Schiavoni, S. (2015), “A review of unconventional sustainable building insulation materials", Sustainable Materials and Technologies, Elsevier B.V., Vol. 4, pp. 1-17.

Aswale, S. (2015), "Brick making in india - history", International Journal of Financial Services Management, Vol. 4, available at: https://doi.org/https://www.researchgate.net/publication/295387059_BRICK_MAKING_IN_INDIA_HISTORY.

Awasthi, A., Singh, N., Mittal, S., Gupta, P.K. and Agarwal, R. (2010), "Effects of agriculture crop residue burning on children and young on PFTs in North West India”, Science of the Total Environment, Elsevier B.V., Vol. 408 No. 20, pp. 4440-4445.

Baig, M. (2010), "Biomass: Turning agricultural waste to green power in India", Www.Abccarbon.Com, available at: http://abccarbon.com/biomass-turning-agricultural-waste-to-green-power-in-india/ (accessed 20 October 2018).

Banerjee, S. (2015), "Brick kilns contribute about 9 per cent of total black carbon emissions in India", Cseindia.Org, available at: http://www.cseindia.org/brick-kilns-contribute-about-9-per-cent-of-total-blackcarbon-emissions-in-india-5713.

El-Turki, A., Ball, R.J. and Allen, G.C. (2007), "The influence of relative humidity on structural and chemical changes during carbonation of hydraulic lime", Cement and Concrete Research, Vol. 37 No. 8 , pp. 1233-1240.

Gadling, P. and Varma, M.B. (2016), "Comparative study on fly ash bricks and normal clay bricks comparative study on fly ash bricks and normal clay bricks", No. January 2016, pp. 5-9.

Hammond, G.P. and Jones, C.I. (2008), “Embodied energy and carbon in construction materials", Proceedings of the Institution of Civil Engineers - Energy, Vol. 161 No. 2, pp. 87-98. 
Ip, K. and Miller, A. (2012), "Life cycle greenhouse gas emissions of hemp-lime wall constructions in the UK", Resources, Conservation and Recycling, Elsevier B.V., Vol. 69, pp. 1-9.

Jain, N., Bhatia, A. and Pathak, H. (2014), "Emission of air pollutants from crop residue burning in India", Aerosol and Air Quality Research, Vol. 14 No. 1, pp. 422-430.

Kulkarni, N.G. and Rao, A.B. (2016), “Carbon footprint of solid clay bricks fired in clamps of India”, Journal of Cleaner Production, Elsevier Ltd, Vol. 135, pp. 1396-1406.

Loganathan, S., Srinath, P., Kumaraswamy, M., Kalidindi, S. and Varghese, K. (2017), "Identifying and addressing critical issues in the Indian construction industry: Perspectives of large building construction clients", Journal of Construction in Developing Countries, Vol. 22, pp. 121-144.

Madurwar, M. V, Ralegaonkar, R. V and Mandavgane, S.A. (2013), “Application of agro-waste for sustainable construction materials: A review”, Construction and Building Materials, Elsevier, Vol. 38, pp. 872-878.

Magwood, C. (2017), "Introduction to natural hempcrete construction methods", GreenHome Institute, available at: https://www.youtube.com/watch?v=yIldL6QRtLo (accessed 4 May 2018).

Meyer, C. (2009), "The greening of the concrete industry", Cement and Concrete Composites, Elsevier Ltd, Vol. 31 No. 8, pp. 601-605.

Morris, A.S., Udayan Dhavalikar, V.A.S. (2016), "Examination of Affordable Housing Policies in India".

Oyenuga, A.A., Bhamidimarri, R. and Researcher, P.D. (2017), "Upcycling ideas for sustainable construction and demolition waste management: Challenges, opportunities and boundaries", International Journal of Innovative Research in Science, Engineering and Technology (An ISO, Vol. 6 No. 3, available at:https://doi.org/10.15680/IJIRSET.2017.0603187.

De Pandit, S. (2017), "The role of the pradhan mantri awas yojana (urban), 2015 in financial inclusion in India", International Journal of Recent Scientific Research, Vol. 8 No. 8, pp. 18959-18962.

PHFI and CEH. (2017), "Air pollution and health in india : a review of the current evidence and opportunities for the future", available at: https://www.ceh.org.in/wp-content/uploads/2017/10/Air-Pollution-and-Health-inIndia.pdf.

Prétot, S., Collet, F. and Garnier, C. (2014), "Life cycle assessment of a hemp concrete wall: Impact of thickness and coating", Building and Environment, Elsevier, Vol. 72, pp. 223-231.

Satpathy, I., Malik, J.K., Arora, N., Kapur, D.S., Saluja, S., Bhattacharjya, S. and Sekhar, A.R. et al. (2016), "Material consumption patterns in India", p. 24.

Saviour, M.N. (2012), "Environmental Impact of Soil and Sand Mining: a Review", International Journal of Science, Environment and Technology, Vol. 1 No. 3, pp. 125-134 Review.

Singh, V.K. (2017), "Alternative utilization of crop residues: Tackling negative impacts of burning in India", Krishijagran.Com, available at: https://krishijagran.com/featured/alternative-utilization-of-crop-residuestackling-negative-impacts-of-burning-in-india (accessed 27 October 2018).

Singh, Y. and Sidhu, H.S. (2014), "Management of cereal crop residues for sustainable rice-wheat production system in the indo-gangetic plains of India", Proceedings of the Indian National Science Academy, Vol. 80 No. 1, pp. 95-114.

Son, N.K., Toan, N.P.A., Dung, T.T.T. and Huynh, N.N.T. (2017), "Investigation of agro-concrete using byproducts of rice husk in mekong delta of vietnam", Procedia Engineering, Vol. 171, pp. 725-733.

UN. (1987), "United nations: Our common future", available at: https://dx.doi/org/10.2307/2621529.

Walker, R. and Pavía, S. (2014), "Moisture transfer and thermal properties of hemp-lime concretes", Construction and Building Materials, Elsevier Ltd, Vol. 64, pp. 270-276. 